СИНТЕЗ ТА АНАЛІЗ БІОЛОГІЧНО АКТИВНИХ РЕЧОВИН

\author{
V. V. Kachaniuk ${ }^{1}$, V. M. Shevel ${ }^{2}$ \\ ${ }^{1}$ Ukrainian Military Medical Academy, Ukraine \\ ${ }^{2}$ Institute of Nuclear Research of the National Academy of Sciences of Ukraine, Ukraine
}

\title{
The substantiation of the quality control method for determining the radionuclide purity and the total radioactivity of radiopharmaceuticals
}

The quality control in the manufacture of radiopharmaceuticals has a prominent role in providing the supply of high-quality drugs for the diagnosis and treatment of patients with cancer. It has been determined that the permission to use radiopharmaceuticals directly depends on the results of the analytical control.

Aim. To reduce the time for the quality control of radiopharmaceuticals, resulting in both the radiochemical yield of the product and its specific activity. This is an important parameter in conducting diagnostic or therapeutic procedures.

Materials and methods. To optimize the process of the quality control for radiopharmaceuticals we propose to replace the following laboratory equipment: a Moleculer Mol gamma spectrometer, which monitors the radionuclide purity of radiopharmaceuticals (gamma-ray energy measurement) and a BIODEX ATOMLAB 500 preloaded device (measurement of the total radioactivity of a drug) to a radionuclide calibrator for nuclear medicine developed by domestic scientists of the Institute of Scintillation Materials and made at the "Kvant" X-ray equipment plant in Kharkiv.

Results and discussion. It has been proven that the use of calibrator radiopharmaceuticals for nuclear medicine should be applied as the quality control. It has been substantiated that the calibrator of doses for nuclear medicine performs two functions simultaneously.

Conclusions. The method of optimization of the quality control of radiopharmaceuticals using the device - a radionuclide calibrator for nuclear medicine allows us to simultaneously obtain the results of the analysis by such indicators as "radionuclide purity" and "radioactivity".

Key words: quality control; radiopharmaceuticals; radionuclide calibrator for nuclear medicine; radionuclide purity; radioactivity

В. В. Качанюк ${ }^{1}$, В. М. Шевель ${ }^{2}$

${ }^{1}$ Військова медична академія України, Україна

2 Інститут ядерних досліджень Національної академії наук України, Україна

Обґрунтування методу контролю якості для визначення радіонуклідної чистоти та загальної радіоактивності радіофармацевтичних препаратів

Контроль якості у виробництві радіофармацевтичних препаратів відіграє важливу роль у забезпеченні постачання високоякісних препаратів для діагностики та лікування хворих на рак. Дозвіл на використання радіофармацевтичних препаратів безпосередньо залежить від результатів аналітичного контролю.

Мета роботи - скорочення часу для контролю якості радіофрармацевтичних препаратів, що дозволить збільшити як радіохімічний вихід продукту, так і його специфічну активність, що є важливим параметром при проведенні діагностичних або терапевтичних процедур.

Матеріали та методи. Для оптимізації процесу контролю якості радіофармацевтичних препаратів пропонується замінити лабораторне обладнання: гамма-спектрометр Moleculer Mol, який застосовується для визначення радіонуклідної чистоти радіофармпрепаратів (вимірювання гамма-енергії) і BIODEX ATOMLAB 500 (вимірювання загальної радіоактивності препарату), на радіонуклідний калібратор для ядерної медицини, розроблений вітчизняними вченими інституту сцинтиляційних матеріалів та виготовлений на заводі рентгенівського обладнання «Квант» м. Харків.

Результати та їх обговорення. Доведено, що використання радіоактивних медичних препаратів калібратора для ядерної медицини має бути залучене як перевірка якості. Обгрунтовано, що калібратор доз для ядерної медицини виконує дві функції одночасно.

Висновки. Оптимізація здійснення контролю якості радіофармацевтичних препаратів за допомогою приладу - радіонуклідного калібратора для ядерної медицини дає змогу одночасно отримувати результати аналізу за показниками: «радіонуклідна чистота » і «загальна радіоактивність».

Ключові слова: контроль якості; радіофармацевтичні препарати; радіонуклідний калібратор для ядерної медицини; радіонуклідна чистота; загальна радіоактивність 
В. В. Качанюк', В. Н. Шевель²

${ }^{1}$ Военная медицинская академия Украины, Украина

2 Институт ядерных исследований Национальной академии наук Украины, Украина

\section{Обоснование метода контроля качества для определения радионуклидной чистоты и общей радиоактивности радиофармацевтических препаратов}

Контроль качества в производстве радиофрармацевтических препаратов играет важную роль в обеспечении поставок высококачественных препаратов для диагностики и лечения онкологических заболеваний. Определено, что разрешение на использование радиофрармацевтических препаратов напрямую зависит от результатов аналитического контроля.

Цель работы - сокращение времени для проведения контроля качества радиофармацевтических препаратов, в следствие чего, увеличится как радиохимический выход продукта, так и его специфическая активность, что является важным параметром при проведении диагностических или терапевтических процедур.

Материалы и методы. Для оптимизации процесса контроля качества радиофармацевтических препаратов предлагается заменить лабораторное оборудование: гамма-спектрометр Moleculer Mol, применяемый для определения радионуклидной чистоты радиофармпрепаратов (измерение гамма-энергии) и BIODEX ATOMLAB 500 (измерение общей радиоактивности препарата), на радионуклидный калибратор для ядерной медицины, разработанный отечественными учеными института сцинтилляционных материалов и изготовленный на заводе рентгеновского оборудования «Квант», г. Харьков.

Результаты и их обсуждение. Доказано, что использование радиоактивных медицинских препаратов калибратора для ядерной медицины должно быть использовано как проверка качества. Обосновано, что калибратор доз для ядерной медицины выполняет две функции одновременно.

Выводы. Оптимизация контроля качества радиофармацевтических препаратов с использованием прибора радионуклидного калибратора для ядерной медицины позволяет одновременно получать результаты анализа по показателям: «радионуклидная чистота» и «общая радиоактивность».

Ключевые слова: контроль качества; радиофрармацевтические препараты; радионуклидный калибратор для ядерной медицины; радионуклидная чистота; общая радиоактивность

Introduction. The quality control in the manufacture of radiopharmaceuticals plays an important role in providing the supply of high-quality drugs for the diagnosis and treatment of patients with cancer. The permission to use radiopharmaceuticals directly depends on the re sults of the analytical control [1].

The aim of the work is to reduce the time for the quality control of radiopharmaceuticals, resulting in both the radiochemical yield of the product and its specific activity. This is an important parameter in conducting diagnostic or therapeutic procedures.

Materials and methods. To optimize the process of the quality control for radiopharmaceuticals we propose to replace the following laboratory equipment: a Moleculer Mol gamma spectrometer, which monitors the radionuclide purity of radiopharmaceuticals (gammaray energy measurement) and a BIODEX ATOMLAB 500 preloaded device (measurement of the total radioactivity of a drug) to a radionuclide calibrator for nuclear medicine developed by domestic scientists of the Institute of Scintillation Materials and made at the "Kvant" $\mathrm{X}$-ray equipment plant in Kharkiv [2].

Results and discussion. Taking into account that the majority of radiopharmaceuticals have a short shelf life it is necessary to solve a difficult task - to optimize the quality control process.

Reducing the time for the quality control will increase both the radiochemical yield of the product and its specific activity, which is an important parameter for conducting diagnostic or therapeutic procedures with the use of radiopharmaceuticals.

The radionuclide calibrator proposed for nuclear medicine has smaller dimensions and weight compared to its analogs, and determines the total radioactivity of radionuclide and the radionuclide purity simultaneously $[3,4]$.

The radionuclide calibrator has the software that allows obtaining spectra, visualization of the radionuc lide activity in the sample, as well as information concerning the presence of impurities. In addition, there is a function of printing information on paper carriers.

This equipment was used in the studies conducted in the conditions of real measurements of radioactivity and the radionuclide purity of perutecnetate eluate $99 \mathrm{~m}$ $\left({ }^{99} \mathrm{Tc}\right)$ obtained from a centralized extraction generator on the experimental nuclear reactor of the Institute of Nuclear Research of the NAS of Ukraine (Fig. 1, 2).

The gamma spectra of radiopharmaceuticals were measured on the basis of Fludeoxyglucose 18F, solution for injections (FDG) and determination of the drug activity $[5,6]$.

The research was carried out in three batches of FDG of various activities: 20181228/184, 20181228/185 and

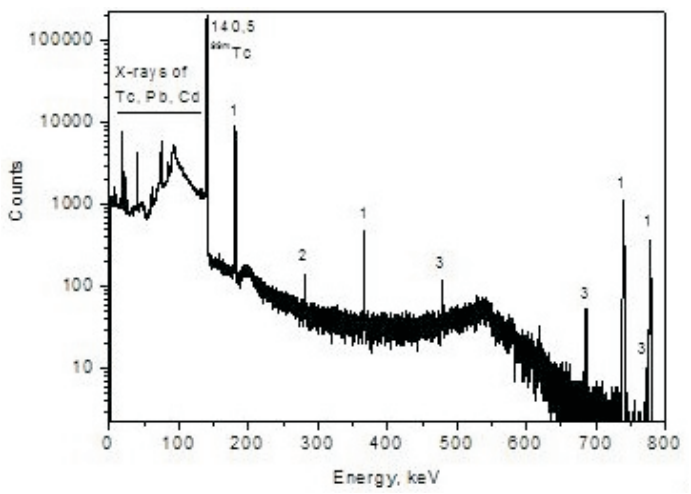

Fig. 1. The gamma spectrum of the sample ${ }^{99} \mathrm{Mo}+{ }^{99} \mathrm{TC}$ 


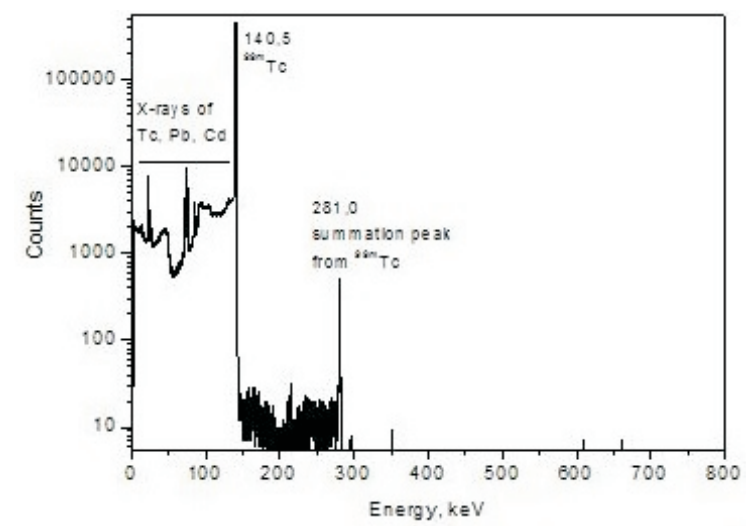

Fig. 2. The gamma spectrum of the sample ${ }^{99} \mathrm{Tc}$

20181229/186. The half-life was $2 \mathrm{~h}$; the probability of decay via the channel was $96 \%$. To determine the radioactivity of radiopharmaceuticals, the geometry of the data was used, the recording efficiency, and the photopic area $(511 \mathrm{keV})$ were used. From these data, the calculation of radioactivity was performed according to the formula:

$$
A=\frac{S 0}{\varepsilon \cdot \Omega \cdot w \cdot k \cdot c \cdot t},
$$

where: $\mathrm{A}-$ is the activity $(\mathrm{Bq})$; $\mathrm{S} 0$ - is the square under the peak; $\varepsilon-$ is the efficiency of recording gamma quanta with an energy of $511 \mathrm{keV} ; \Omega$ - is the solid angle (determined by the geometry of measurement); $\mathrm{w}-$ is the quantum yield (takes into account that 2 decomposition gamma rays appear per 1 decay act); $\mathrm{k}$ - is the coefficient that takes into account the probability of decay via the required channel $(\mathrm{EC}-0.96)$; $\mathrm{c}$ - is the coefficient that takes into account the attenuation due to protection; $\mathrm{t}$ - is the measurement time (for all batches $300 \mathrm{sec}$.).

The gamma-spectra and the results of the activity determination are shown in Fig. 3.

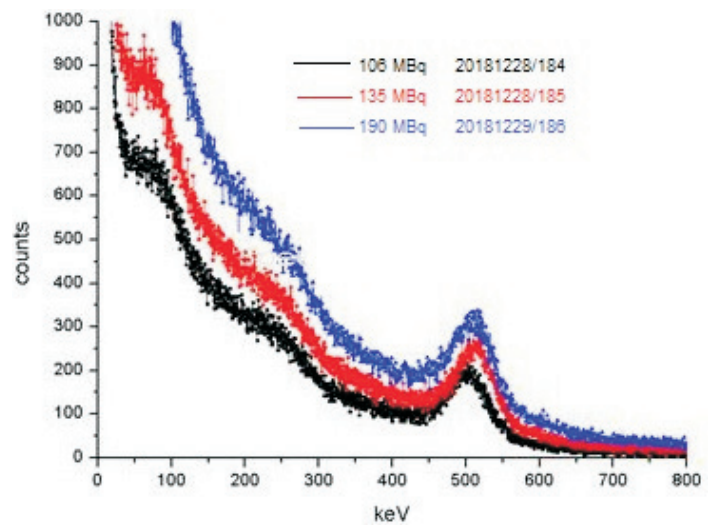

Fig. 3. The gamma spectra of three batches of FDG
Using the radionuclide calibrator for nuclear medicine the results of the FDG quality control have been obtained: the gamma radiation spectrum corresponds to $511 \mathrm{keV}$ in all batches studied. The total radioactivity of the sample batches: for $20181228 / 184$ is $106 \mathrm{MBq}$, for $20181228 / 185$ is $135 \mathrm{MBq}$ and for $20181229 / 186$ is $190 \mathrm{MBq}$.

\section{Conclusions and prospects of further research}

1. A calibrator of doses for nuclear medicine performs two functions simultaneously: it measures the total radioactivity and determines the radionuclide purity of a solution; it reduces the time for the quality control of radiopharmaceuticals.

2. This device is of domestic production; it is cheaper and easier to use than foreign analogs.

3. The optimization of the method of conducting the quality control of radiopharmaceuticals has been implemented at the All-Ukrainian Center for Radiation Surgery in the Clinical Hospital "Feofaniya" of the State Department of Affairs in accordance with the GMP requirements.

Conflict of interests: authors have no conflict of interests to declare.

\section{REFERENCES}

1. Лікарські засоби. Належна виробнича практика : настанова СТ-Н МОЗУ 42-3.5:2016. [чинний від 2016-07-29]. Вид. офіц. Київ : Міністерство охорони здоров'я України, 2016. - 120 с.

2. Радіонуклідний калібратор для ядерної медицини : Пат. 60782 Україна: МПК (2011.01), G 01 Т 1/00; заявл.: 25.06.2011.

3. Спосіб промислового виробництва екстракційного технецію 99М : Пат. 86967_2 Україна; заявл.: 10.01.2014.

4. Державна фармакопея України. Друге видання. Радіофармацевтичні лікарські засоби : наказ Міністерства охорони здоров’я України № 476 від 14.03.2018 р. - С. 1047-1053.

5. Семенів, І. П. Досвід впровадження та перші підсумки застосування позитронно-емісійної томографії у Всеукраїнському центрі радіохірургії / І. П. Семенів, Я. В. Кметюк, О. І. Москалець // Променева діагностика. Променева терапія. - 2013. - № 2-3. C. $88-92$.

6. Качанюк, В. В. Розроблення технології та методів контролю якості радіофармацевтичного препарату Фтордезоксиглюкоза $18 \mathrm{~F}$, розчин для ін’єкцій / В. В. Качанюк, В. В. Трохимчук, С. Ю. Саричев // Фармац. журн. - 2017. - № 1. - С. 51-58.

\section{REFERENCES}

1. Nastanova ST-N MOZU 42-3.5:2016. (2016). Likarski zasoby. Nalezhna vyrobnycha praktyka. Vydannia ofitsiine. Kyiv: Ministerstvo okhorony zdorovia Ukrainy,120.Radionuklidnyi kalibrator dlya yadernoyi medytsyny: pat. 60782 Ukrayina: MPK (2011.01), G01T 1/00; 25.06.2011.

2. Pat. 60782 Ukraina: MPK (2011.01), G01T 1/00. (2011). Radionuklidnyi kalibrator dlia yadernoi medytsyny.

3. Pat.86967_2 Ukraina. (2014). Sposib promyslovoho vyrobnytstva ekstraktsiinoho tekhnetsiiu 99M.

4. Derzhavna farmakopeia Ukrainy. (2-edition). (2018). Radiofarmatsevtychni likarski zasoby, 1047-1053. Nakaz Ministerstva okhorony zdorov'ia Ukrainy №476 vid 14.03.2018 r.

5. Semeniv, I. P., Kmetiuk, Ya. V., Moskalets, O. I. (2013). Promeneva diahnostyka. Promeneva terapiia, 2-3, 88-92.

6. Kachaniuk, V. V., Trokhymchuk, V. V., Sarychev, S. Yu. (2017). Farmatsevtychnyi zhurnal, 1, 51-58. 


\section{Information about authors:}

Kachaniuk V. V., senior teacher of the Department of Military Pharmacy, Ukrainian Military Medical Academy. E-mail: Kachanjuk@ukr.net

Shevel V. M., deputy chief engineer of the Department of Research Nuclear Reactor, Institute of Nuclear Research of the National Academy of Sciences of Ukraine. E-mail: Shevel@nas.gov.ua

Відомості про авторів:

Качанюк В. В., старший викладач кафедри військової фармації, Українська військово-медична академія. E-mail: Kachanjuk@ukr.net

Шевель В. М., заступник головного інженера відділу дослідницького ядерного реактора, Інститут ядерних досліджень НАН України.

E-mail: Shevel@nas.gov.ua

\section{Сведения об авторах:}

Качанюк В. В., старший преподаватель кафедры военной фармации, Украинская военно-медицинская академия.

E-mail: Kachanjuk@ukr.net

Шевель В. Н., заместитель главного инженера отдела исследовательского ядерного реактора, Институт ядерных исследований НАН Украины. E-mail: Shevel@nas.gov.ua 